\title{
Gonadal development and reproductive hormones in infant boys
}

\author{
Katharina M Main, Jorma Toppari ${ }^{1}$ and Niels E Skakkebæk \\ University Department of Growth and Reproduction GR 5064, Rigshospitalet, Blegdamsvej 9, DK-2100 Copenhagen, Denmark and ${ }^{1}$ Departments of \\ Physiology and Paediatrics, University of Turku, Turku, Finland \\ (Correspondence should be addressed to K M Main; Email: katharina.main@rh.hosp.dk)
}

\begin{abstract}
Background: The intrauterine milieu plays a crucial role for cardiovascular and metabolic diseases in adulthood, but little is known about its impact on gonadal development and reproduction. Impaired testis development in fetal life can lead to cryptorchidism, hypospadias, impaired semen quality, and testicular cancer, disorders that may present symptoms of a testicular dysgenesis syndrome. The prevalence of these disorders appears to increase in many areas, probably due to environmental factors acting in utero. Denmark has a significantly higher incidence of testicular cancer and lower sperm quality than Finland.

Methods: We conducted a population-based study of newborn boys from Denmark and Finland, in order to examine whether this geographic difference was reflected in the reproductive health of newborns. Results: Danish boys had a lower testis volume at birth, a smaller testis growth up to 18 months of age and lower serum inhibin B and FSH levels at 3 months than Finnish. Danish boys also had a higher prevalence of both cryptorchidism and hypospadias than Finnish boys. In boys with cryptorchidism and hypospadias subtle changes in hormonal levels occurred, towards increased gonadotropins and lower inhibin B in cryptorchidism. Both types of congenital malformations were more frequent in children born small for gestational age, indicative of a relationship between growth and reproductive development.

Conclusions: These early postnatal findings suggest that the previously observed population differences in reproductive health between young Danish and Finnish men are of fetal origin. The differences may originate as a result of gene-environment interactions, where endocrine disrupters may also play a role.
\end{abstract}

European Journal of Endocrinology 155 S51-S57

\section{Introduction}

The intrauterine milieu and the postnatal phase of human fetal development play a crucial role for subsequent morbidity in adult life, i.e. the risk of cardiovascular diseases, diabetes, dyslipidemia, and obesity $(1,2)$. Little is currently known about the impact of fetal life on gonadal function and reproduction in humans (3).

In 2001, a hypothesis of a testicular dysgenesis syndrome (TDS) was suggested, linking adult male reproductive disorders, i.e. impaired semen quality and testicular cancer, with congenital malformations, such as hypospadias and cryptorchidism (4), thereby emphasizing the role of fetal life for reproductive function throughout life. While a small percentage of these reproductive diseases has a detectable genetic or endocrine origin, in the majority of patients the etiology

This paper was presented at the 4th Ferring Pharmaceuticals International Paediatric Endocrinology Symposium, Paris (2006). Ferring Pharmaceuticals has supported the publication of these proceedings. remains unknown. It has been speculated that life style and environmental factors during intrauterine life may play a role (5-7). Prenatal exposure to environmental chemicals may also play a role, i.e. a picture similar to the human TDS could be induced in rats by in utero exposure of male offspring to dibutyl phthalate (8), a chemical ubiquitously used as an additive in household and industrial products.

The following review summarizes present evidence that the fetal and postnatal periods are important for reproductive development by using Denmark and Finland as a model of two countries with a large difference in male reproductive health in adult men; Denmark having a considerably higher incidence of testicular cancer (9) and lower semen quality (10) than Finland.

\section{Postnatal reproductive hormones and genital growth in healthy boys}

Shortly after birth, a brief activation of the hypothalamus-pituitary-gonadal axis with an increase of follicle-stimulating hormone (FSH) and luteinizing hormone (LH) leads to a peak in reproductive hormones, 
such as testosterone, inhibin $\mathrm{B}$, and anti-Müllerian hormone (AMH) (11-17). It has been known for many decades, that this feature can be utilized clinically, i.e. in diagnosing hypogonadotropic hypogonadism $(18,19)$ and studying primary testicular dysfunction, i.e. in Klinefelter syndrome $(20,21)$. Measurement of inhibin B and AMH during this period can also be used as a marker of the presence of testicular tissue in conditions like bilateral cryptorchidism with non-palpable testes and disorders of gender differentiation (22).

The biological significance of the postnatal hormonal surge in healthy boys is not yet fully understood. As serum levels of sex hormone-binding globulin increase parallel to the gonadotropins and testosterone, it was assumed that very little free testosterone was available and thus biologically active. As a consequence, there is some dispute as to whether the free fraction of testosterone in humans increases during this postnatal peak (23) or not (24). It has, however, been shown in three patients with gonadotropin insufficiency that the postnatal development of scrotum and penis was compromised if the testosterone surge did not occur, and testes ascended (25). These symptoms could be reversed with androgen or gonadotropin treatment (18).

During the postnatal phase, testis development continues (26). Leydig cell proliferation and germ cell differentiation are dependent on an intact gonadotropin and androgen action (27). In primates, manipulation of the postnatal testosterone levels has shown distinct effects on phallic growth, sexual behavior, and reproduction (28-30). The postnatal rise in inhibin B is associated with an increase in the number of Sertoli cells $(31,32)$, which in turn may reflect future potential for sperm production $(33,34)$. Also, the number of Leydig and germ cells increases transiently during the first 3 months of life, and the development of the two testicular cell lines, Sertoli and Leydig cells, are closely interlinked $(35,36)$.

Whereas the efficacy of exogenous testosterone in the treatment of micropenis has been established for some time (37), it was only recently shown that endogenous testosterone secretion was also important for penile growth. In 1962 healthy Danish and Finnish boys born at term with normal birth weight, penile length increased approximately $1 \mathrm{~cm}$ from birth to 3 years of age. Both penile length at 3 months and penile growth rate between birth and 3 months of age were significantly correlated with testosterone and free testosterone, in addition to other factors, such as body height and weight. Body mass index was negatively correlated to penile length, which could indicate technical difficulties with measurement accuracy or an altered estrogen-androgen balance through increased aromatase activity in fat tissue (38).

Penile length measurements did not differ significantly between healthy Danish and Finnish boys and corresponded well to previous standards for penile length in Caucasian populations $(39,40)$. This binational Nordic study, however, revealed a significant population difference in testis size and the serum level of Sertoli cell marker inhibin B at 3 months $(32,41)$. Testis volume was measured by ultrasound, which provided a better sensitivity than an orchidometer. Testicular volume in Danish boys was approximately 3\% lower than in Finnish boys at birth, a difference that increased to $36 \%$ at 3 months and $28 \%$ at 18 months. This was still true when testis volume measurements were adjusted for body surface area to correct for differences in body size between populations. At the same time, both FSH and inhibin B levels were 9 and 16\% lower respectively in Danish than in Finnish boys. There was a positive correlation between the serum concentration of inhibin $\mathrm{B}$ and testicular volume, as seen previously in adults and pubertal boys (42), and the ratio between inhibin B and FSH did not differ between the countries. The hormonal findings and differences in testis volume taken together were indicative of a higher set point of the pituitarygonadal axis in Finnish boys due to a larger pool of seminiferous tubules. During the postnatal period, Sertoli cells still replicate in humans $(26,43,44)$. Postnatal testicular growth consists of an increase in the length of seminiferous tubules, and total number of germ and Sertoli cells, and a decreased apoptosis of Sertoli cells (43-47). Postnatal reduction in Sertoli cell number in rats leads to a decreased Sertoli cell pool in adult animals and reduced sperm production (48). Disturbance of the postnatal gonadotropin surge compromised replication of Sertoli cells in the Marmoset monkey (49). Thus, the findings suggested that the Danish boys were born with a smaller Sertoli cell pool, which in addition did not grow to the same extent as in the Finnish boys.

Danish adult men have a lower testis volume and lower semen quality than Finnish men, and there is a correlation between testis size and semen quality (10). Danish men also have a higher risk of testicular cancer than Finnish men $(9,50)$. Thus, the observations in newborn boys are in line with findings in adult men and indicate a fetal origin of the geographic difference. Although the long-term biological consequence of the smaller testis size in Danish boys is yet unknown, it may be a subtle sign of a perinatal testicular dysgenesis. This, in turn, may lead to a higher risk of impaired semen quality and development of testicular cancer in adulthood (51).

\section{Prevalence of cryptorchidism and hypospadias}

Highly variable prevalence rates of cryptorchidism $(2-7 \%)$ have been reported in western countries on the basis of registry studies $(52,53)$. Such studies are, however, seriously hampered by a lack of standardization in diagnostic procedures and stringency in reporting to registries (54). Cryptorchidism is often regarded as a minor malformation, and therefore not systematically reported. In consequence, prevalence 
data from cohort studies tend to be higher than from registries (55-58). Due to spontaneous testicular descent and changes in treatment standards, the prevalence of orchidopexy cannot be applied as a substitute for population-based data (59-61) to study geographic or temporal trends.

There appear to be regional differences in the prevalence of cryptorchidism and an increase over time (52). Our binational study revealed a large difference in the prevalence of cryptorchidism between Denmark and Finland (62). Both at birth and at 3 months, Danish boys had a significantly higher rate of cryptorchidism than Finnish boys. The prevalence of congenital cryptorchidism in Denmark was higher, and in Finland lower, than reported from population studies of other countries (55, $58,63,64)$. In the Danish population, a temporal increase from 1.8 in the 1960 s to $8.5 \%$ in the present cohort was observed for boys born with normal birth weight (65). This corresponded with some previous studies from other countries $(52,59,66)$, which also showed an increase of cryptorchidism over time. As cryptorchidism is a main risk factor for testicular cancer and reduced sperm quality (4), the difference in prevalence of congenital cryptorchidism between Denmark and Finland corroborated further the hypothesis of a common prenatal origin of reproductive disorders.

Hypospadias are another relatively common malformation with a reported prevalence of $0.7-1.8$ out of 1000 newborn boys $(67,68)$. Some reports suggest that there is a rise in the prevalence of hypospadias in several, but not all, regions $(52,54,69-73)$. However, most studies were based on registries, which have the same limitations as for cryptorchidism data $(54,74)$. In addition, the mildest and most frequent form of hypospadia, the glanular form, is not registered at all in many registries. Glanular hypospadias may be associated with a normal foreskin, and thus first become detectable after the dissolution of the physiological phimosis (75) and often remain undiagnosed throughout life.

Denmark had a significantly higher prevalence of hypospadias at birth than Finland $(74,75)$ and also a higher number of severe cases. The systematic follow-up of the Danish boys allowed the detection of a substantial number of additional cases of mild hypospadias after the dissolution of the physiological phimosis. This resulted in a point prevalence of $4.6 \%$ at 3 years of age. This number could potentially increase further with age, as the prepuce could only be retracted in two-thirds of the boys at 3 years. The Danish prevalence, even at birth, was considerably higher than previously reported for Denmark or other countries $(67-69,76)$, but due to the above-mentioned imprecision of registry data and differences in cohort study designs, no temporal trends could be determined with certainty. Again, the geographic difference in the prevalence of hypospadias between the two Nordic countries was in favor of Finland, and thus in line with data on congenital cryptorchidism, semen quality, and testicular cancer incidence.

Low birth weight, either defined as $<2500 \mathrm{~g}$ or as weight for gestational age $<-2$ S.D., is a known strong risk factor for both cryptorchidism and hypospadias (3, 77). In the joint Danish-Finnish cohort study, low birth weight increased the risk of cryptorchidism two- to threefold. Prematurity was an additional risk factor for cryptorchidism, although boys were examined corrected for the expected date of birth. However, the country difference in the prevalence of cryptorchidism was not explained by birth weight or frequency of prematurity, as the largest geographical difference was observed for children with normal birth weight and born at term.

In boys with hypospadias, birth weight for gestational age and placenta weight were significantly lower than in control boys, with an association with the severity of hypospadias. In coronal and penile hypospadias also, birth length and head circumference were significantly smaller. Such associations with size at birth have also been reported from previous register and population studies (77-82). The longitudinal follow-up revealed that this difference in body size tended to persist throughout infancy, as body weight and height were still significantly smaller than in controls at 3 years of age. It has previously been hypothesized that the gender dimorphism of birth weight and length was caused by fetal androgens $(83,84)$. In our study, boys with severe forms of hypospadias had a birth weight and length similar to or even lower than girls from the same cohort (85), which is similar to another previous report (86). In healthy boys, weight for gestational age was positively correlated with testicular volume (41). This association was most pronounced at birth, but persisted through infancy. There therefore appears to be an interaction between fetal growth and genital development, the direction of which is yet unclear.

\section{Postnatal reproductive hormones in boys with cryptorchidism and hypospadias}

A normal function of the hypothalamic-pituitarygonadal axis is necessary for normal testicular development and descent $(87,88)$, including gonadotropins, testosterone, and insulin-like hormone 3 (89). In return, persistent malposition of the testes themselves leads to increased loss of germ cells (90). Congenital cryptorchidism increases the risk for fertility problems and testicular cancer in adulthood (91-94). While Leydig cell function and loss of germ cells appear to benefit to some degree from early treatment $(95,96)$, the risk of testicular cancer appears to remain unaltered after orchidopexy (91), which indicates a prenatal, irreversible onset of the testicular dysgenesis (4). There was some controversy in the literature as to when in life hormonal changes related to maldescended testes were 
detectable, i.e. the increase in gonadotropin drive due to reduced testosterone and inhibin $B$ secretion, and whether they are the cause or consequence of the disorder (97-100).

In our cohort (101), the Finnish boys with cryptorchidism showed significantly higher FSH and lower inhibin B levels than healthy controls. Changes were most pronounced in severe cryptorchidism, which persisted from birth to 3 months of age. In this group also, a significant effect on Leydig cell function was seen, with increased LH and LH:testosterone ratio. However, boys with very mild forms of cryptorchidism, i.e. high scrotal testis, or transient forms, i.e. with spontaneous descent between birth and 3 months of age, also showed a subtle impairment of Sertoli cell function. In the Danish cohort, inhibin B concentrations did not differ between controls and cryptorchid boys of any severity, probably due to the lower set point of the pituitarygonadal axis in the Danish boys as mentioned earlier. However, also in the Danish cohort, an increase in gonadotropins was found in persistent severe cryptorchidism. These findings were in line with previous studies (95, 102-106). As boys with congenital cryptorchidism already showed a subtle impairment of primary testicular function at 3 months of age, this was likely to be of fetal origin. An increased drive of gonadotropins was also found in mild and transient forms of cryptorchidism, i.e. a high scrotal position was also indicative of a subtle testicular dysgenesis, and spontaneous descent did not ameliorate testicular function. These novel findings will have to be followed up into adulthood to establish whether they are of biological significance.

Previous studies on hormonal parameters or fertility in patients with hypospadias are very limited (107-110). In our study (75), a significantly increased FSH and FSH:inhibin B ratio were found in boys with hypospadias. We have previously demonstrated that there is an interrelation between hormones related to Sertoli and Leydig cell functions during the postnatal surge, i.e. between inhibin B and LH or testosterone respectively. Although urethral fusion itself is thought to be predominantly dependent on testosterone (111), this finding was thus in line with the hypothesis of a TDS affecting all testicular cell types simultaneously.

\section{Summary and conclusions}

Fetal life and the immediate postnatal period are important for the development of the testes. Malformations, such as cryptorchidism and hypospadias are well-known indicators of disturbed testicular development and are closely related to fetal growth. However, neonatal testicular size and testes growth, as well as the level of reproductive hormones during the postnatal hormonal surge, can also reveal disturbances of perinatal testicular development in otherwise healthy
Table 1 Regional differences in male reproductive health between Denmark and Finland.

\begin{tabular}{lll}
\hline & Denmark & Finland \\
\hline $\begin{array}{l}\text { Incidence of testicular cancer } \\
\begin{array}{l}\text { Prevalence of cryptorchidism and } \\
\text { hypospadias }\end{array}\end{array}$ & $\begin{array}{l}\text { Higher } \\
\text { Higher }\end{array}$ & Lower \\
$\begin{array}{l}\text { Semen quality } \\
\text { Infant testis volume }\end{array}$ & Lower & Higher \\
Postnatal serum inhibin B & Lower & Higher \\
\hline
\end{tabular}

boys, which may be of consequence for adult life. This enables research into disruptive factors for testicular development that are active during pregnancy without having to wait for full maturation.

Significant population differences in the reproductive health of newborn boys were seen between Denmark and Finland. Danish boys did not only show a significantly higher rate of congenital cryptorchidism and hypospadias than Finnish, but there was also a significant difference in testis size and in the serum level of the Sertoli cell marker inhibin B in healthy boys. These findings were consistent with the well-characterized differences in adult male reproductive health between the two countries, with Denmark having a higher rate of impaired semen quality and testicular cancer than Finland (Table 1). The findings support the hypothesis of an intrauterine TDS that appears to be more frequent in Denmark than in Finland. In addition to possible genetic differences between these two populations, the lifestyle or environmental factors seem to play a role.

\section{Acknowledgements}

The Danish-Finnish birth cohort study was supported by the European Commission (QLK4-CT1999-01422, QLK-2001-00269, QLK4-2002-0063), The Danish Medical Research Council (9700833 and 9700909), the Sven Andersens and Velux Foundations, the Novo Nordisk Foundation, Sigrid Jusélius Foundation, The Turku University Central Hospital, and the Academy of Finland.

\section{References}

1 Barker DJP, Gluckman PD, Godfrey KM, Harding JE, Owens JA \& Robinson JS. Fetal nutrition and cardiovascular disease in adult life. Lancet 1993341 938-941.

2 Ibanez L, Ong KK, Dunger DB \& De Zegher F. Early development of adiposity and insulin resistance following catch-up weight gain in small - for gestational age children. Journal of Clinical Endocrinology and Metabolism 200691 2153-2158

3 Main KM, Jensen RB, Asklund C, Høi-Hansen CE \& Skakkebæk NE. Low birth weight and male reproductive function. Hormone Research $2006 \mathbf{6 5} 116-122$. 
4 Skakkebæk NE, Rajpert-De Meyts E \& Main KM. Testicular dysgenesis syndrome: an increasingly common developmental disorder with environmental aspects. Human Reproduction 2001 16 972-978.

5 Skakkebæk NE. Testicular dysgenesis syndrome: new epidemiological evidence. International Journal of Andrology 2004 27 189-191.

6 Sultan C, Balaguer P, Terouanne B, Georget V, Paris F, Jeandel C, Lumbroso S \& Nicolas J. Environmental xenoestrogens, antiandrogens and disorders of male sexual differentiation. Molecular and Cellular Endocrinology 2001178 99-105.

7 Sharpe RM. Pathways of endocrine disruption during male sexual differentiation and masculinization. Baillières Best Practice and Research Clinical Endocrinology and Metabolism 200620 91-110.

8 Fisher JS, Macpherson S, Marchetti N \& Sharpe RM. Human 'testicular dysgenesis syndrome': a possible model using in utero exposure of the rat to dibutyl phthalate. Human Reproduction 200318 1383-1394.

9 Purdue MP, Devesa SS, Sigurdson AJ \& McGlynn KA. International patterns and trends in testis cancer incidence. International Journal of Cancer 2005115 822-827.

10 Jørgensen N, Carlsen E, Nermoen I, Punab M, Suominen J, Andersen A-G, Andersson AM, Haugen TB, Horte A, Jensen TK, Magnus O, Petersen JH, Vierula M, Toppari J \& Skakkebæk NE. East-East-West gradient in semen quality in the Nordic-Baltic area: a study of men from the general population in Denmark, Norway, Estonia and Finland. Human Reproduction 200217 2199-2208.

11 Forest MG, De Peretti E \& Bertrand J. Hypothalamic-pituitarygonadal relationships in man from birth to puberty. Clinical Endocrinology 19765 551-569.

12 Winter JSD, Hughes IA, Reyes FI \& Faiman C. Pituitary-gonadal relations in infancy:2. Patterns of serum gonadal steroid concentrations in man from birth to two years of age. Journal of Clinical Endocrinology and Metabolism 197642 679-686.

13 Winter JSD. Hypothalamic-pituitary function in the fetus and infant. Journal of Clinical Endocrinology and Metabolism 198211 $41-55$.

14 Andersson A-M, Toppari J, Haavisto A-M, Petersen JH, Simell T, Simell O \& Skakkebæk NE. Longitudinal reproductive hormone profiles in infants: peak of inhibin B levels in infant boys exceeds levels in adult men. Journal of Clinical Endocrinology and Metabolism $1998 \mathbf{8 3} 675-681$.

15 von Bidlingmaier F. Geschlechtsunterschiede der Sekretion von Gonadotropinen und Sexualhormonen im Säuglings- und Kleinkindesalter. Fortschritt der Medizin 19807 235-238.

16 Tapanainen J. Hormonal changes during the perinatal period: serum testosterone, some of its precursors, and FSH and prolactin in preterm and fullterm male infant cord blood and during the first week of life. Journal of Steroid Biochemistry 198318 13-18.

17 Lee MM, Donahoe PK, Hasegawa T, Silverman B, Crist GB, Best S, Hasegawa Y, Noto RA, Scheonfeld D \& MacLaughlin DT. Müllerian inhibiting substance in humans: normal levels from infancy to adulthood. Journal of Clinical Endocrinology and Metabolism 199681 571-576.

18 Main KM, Schmidt IM, Toppari J \& Skakkebæk NE. Early postnatal treatment of hypogonadotropic hypogonadism with recombinant human FSH and LH. European Journal of Endocrinology 2002146 75-79.

19 Grumbach MM. A window of opportunity: the diagnosis of gonadotropin deficiency in the male infant. Journal of Clinical Endocrinology and Metabolism $2005903122-3127$.

20 Lahlou N, Fennoy I, Carel J-C \& Roger M. Inhibin B and antiMüllerian hormone, but not testosterone levels, are normal in infants with nonmosaic Klinefelter syndrome. Journal of Clinical Endocrinology and Metabolism 200489 1864-1868.

21 Ross JL, Samango-Sprouse C, Lahlou N, Kowai K, Elder FE \& Zinn A. Early androgen deficiency in infants and young boys with 47 , XXY Klinefelter syndrome. Hormone Research 200564 39-45.
22 Lee MM, Misra M, Donahue PK \& MacLaughlin DT. MIS/AMH in the assessment of cryptorchidism and intersex conditions. Molecular and Cellular Endocrinology 200315 91-98.

23 Forest MG. Pituitary gonadotrophin and sex steroid secretion during the first two years of life. In Control of the Onset of Puberty, pp 451-477. Eds MM Grumbach, PC Sizonenko \& ML Aubert, Baltimore: Williams and Wilkins, 1990.

24 Huhtaniemi I, Dunkel L \& Perheentupa J. Transient increase in postnatal testicular activity is not revealed by longitudinal measurements of salivary testosterone. Pediatric Research 1986 20 1324-1327.

25 Main KM, Schmith IM \& Skakkebæk NE. A possible role for reproductive hormones in newborn boys: progressive hypogonadism without the postnatal testosterone peak. Journal of Clinical Endocrinology and Metabolism 200085 4905-4907.

26 Chemes HE. Infancy is not a quiescent period of testicular development. International Journal of Andrology 200124 2-7.

27 Mann DR \& Fraser HM. The neonatal period: a critical interval in male primate development. Journal of Endocrinology 1996149 191-197.

28 Brown GR, Nevison CM, Fraser HM \& Dixson AF. Manipulation of postnatal testosterone levels affects phallic and clitoral development in infant rhesus monkeys. International Journal of Andrology 199922 119-128.

29 Lunn SF, Cowen GM \& Fraser HM. Blockade of the neonatal increase in testosterone by a GnRH antagonist: the free androgen index, reproductive capacity and postmortem findings in the male marmoset monkey. Journal of Endocrinology $1997 \mathbf{1 5 4} 125-131$.

30 Wallen K, Maestripieri D \& Mann DR. Effects of neonatal testicular suppression with a GnRH antagonist on social behaviour in group-living juvenile rhesus monkeys. Hormones and Behavior $199529322-337$.

31 Cortes D, Müller J \& Skakkebæk NE. Proliferation of Sertoli cells during development of the human testis assessed by stereological methods. International Journal of Andrology 198710 589-596.

32 Andersson A-M. Inhibin B in the assessment of seminiferous tubular function. Baillières Best Practice and Research Clinical Endocrinology and Metabolism 200014 389-397.

33 Andersson A-M, Müller J \& Skakkebæk NE. Different roles of prepubertal and postpubertal germ cells and Sertoli cells in the regulation of serum inhibin B levels. Journal of Clinical Endocrinology and Metabolism $1998 \mathbf{8 3} 4451-4458$.

34 Sharpe RM, McKinnell C, Kivlin C \& Fisher JS. Proliferation and functional maturation of Sertoli cells, and their relevance to disorders of testis function in adulthood. Reproduction $2003 \mathbf{1 2 5}$ 769-784.

35 Müller J \& Skakkebæk NE. Fluctuations in the number of germ cells during the late foetal and early postnatal periods in boys. Acta Endocrinologica 1984105 271-274.

36 Berensztein E, Belgorosky A, de Dávila MR \& Rivarola MA. Basal testosterone secretion and response to human luteinizing, follicle-stimulating, and growth hormones in culture of cells isolated from testes of infants and children. Pediatric Research $199538592-597$.

37 Bin-Abbas B, Conte FA, Grumbach MM \& Kaplan SL. Congenital hypogonadotropic hypogonadism and micropenis: effect of testosterone treatment on adult penile size: why sex reversal is not indicated. Journal of Pediatrics 1999134 579-583.

38 Boas M, Boisen KA, Virtanen HE, Kaleva M, Suomi A-M, Schmidt IM, Damgaard IN, Kai CM, Chellakooty M, Skakkebæk NE, Toppari J \& Main KM. Postnatal penile length and growth rate correlate to serum testosterone levels: a longitudinal study of 1962 normal boys. European Journal of Endocrinology 2006154 125-129.

39 Schonfeld WA \& Beebe GW. Normal growth and variation in the male genitalia from birth to maturity. Journal of Urology $1942 \mathbf{4 8}$ 759-777.

40 Feldman KW \& Smith DW. Fetal phallic growth and penile standards for newborn male infants. Journal of Pediatrics $1975 \mathbf{8 6}$ 395-398. 
41 Main KM, Toppari J, Suomi A-M, Kaleva M, Chellakooty M, Schmidt IM, Virtanen HE, Boisen KA, Kai CM, Damgaard IN \& Skakkebæk NE. Larger testes and higher inhibin B levels in Finnish than in Danish newborn boys. Journal of Clinical Endocrinology and Metabolism 2006 (in press).

42 Crofton PM, Evans AE, Groome NP, Taylor MR, Holland CV \& Kelnar CJ. Inhibin B in boys from birth to adulthood: relationship with age, pubertal stage, FSH and testosterone. Clinical Endocrinology 200256 215-221.

43 Cortes D, Müller J \& Skakkebæk NE. A quantitative histological investigation of the Sertoli cells during human development. In Morphological Basis of Human Reproductive Function, pp 43-44. Eds G Spera \& DM De Kretser, New York and London: Plenum Press, 1987.

44 Müller J \& Skakkebæk NE. Quantification of germ cells and seminiferous tubules by stereological examination of testicles from 50 boys who suffered from sudden death. International Journal of Andrology 19836 143-156.

45 Rey RA, Campo SM, Bedecarrás P, Nagle CA \& Chemes HE. Is infancy a quiescent period of testicular development? Histological, morphometric, and functional study of the seminiferous tubules of the Cebus monkey from birth to the end of puberty. Journal of Clinical Endocrinology and Metabolism 199376 1325-1331.

46 Berensztein E, Saraco N, Belgorosky A \& Rivarola MA. Secretion of inhibin B by human prepubertal testicular cells in culture. European Journal of Endocrinology 2000142 481-485.

47 Sharpe RM, Fraser HM, Brougham MFH, McKinnell C, Dorris KD, Kelnar CJH, Wallace WH \& Walker M. Role of the neonatal period of pituitary-testicular activity in germ cell proliferation and differentiation in the primate testis. Human Reproduction 200318 2110-2117.

48 Orth JM, Gunsalus GL \& Lamperti AA. Evidence from Sertoli celldepleted rats indicates that spermatid number in adults depends on numbers of Sertoli cells produced during perinatal development. Endocrinology 1988122 787-794.

49 Sharpe R, Walker M \& Millar MR. Effect of neonatal gonadotropin-releasing hormone antagonist administration on Sertoli cell number and testicular development in the marmoset: comparison with the rat. Journal of Endocrinology 2000149 191-197.

50 Adami H-O, Bergström R, Möhner M, Zatonski W, Storm H, Ekbom A, Tretli S, Teppo L, Ziegler H, Rahu M, Gurevicius R \& Stengrevics A. Testicular cancer in nine Northern European countries. International Journal of Cancer 199459 33-38.

51 Asklund C, Jørgensen N, Jensen TK \& Skakkebæk NE. Biology and epidemiology of testicular dysgenesis syndrome. British Journal of Urology International 200493 6-11.

52 Paulozzi LJ. International trends in rates of hypospadias and cryptorchidism. Environmental Health Perspectives 1999107 297-302.

53 Toppari J \& Kaleva M. Maldescensus testis. Hormone Research $200651261-269$.

54 Toppari J, Kaleva M \& Virtanen HE. Trends in the incidence of cryptorchidism and hypospadias, and methodological limitations of registry-based data. Human Reproduction Update $20017282-286$.

55 Berkowitz GS, Lapinski RH, Dolgin SE, Gazella JG, Bodian CA \& Holzman IR. Prevalence and natural history of cryptorchidism. Pediatrics 199392 44-49.

56 Preiksa RT, Zilaitiene B, Matulevicius V, Skakkebæk NE, Petersen JH, Jørgensen N \& Toppari J. Higher than expected prevalence of congenital cryptorchidism in Lithuania: a study of 1204 boys at birth and 1 year follow-up. Human Reproduction 200520 1928-1932.

57 Pierik FH, Burdorf A, de Muinck Keizer-Schrama SM, Wolffenbuttel KP, Nijman JM, Juttmann RE \& Weber RF. The cryptorchidism prevalence among infants in the general population of Rotterdam, The Netherlands. International Journal of Andrology 200528 248-252.
58 Ghirri P, Ciulli C, Vuerich M, Cuttano A, Faraoni M, Guerrini L, Spinelli C, Tognetti S \& Boldrini A. Incidence at birth and natural history of cryptorchidism: a study of 10730 consecutive male infants. Journal of Endocrinological Investigation 200225 709-715.

59 Chilvers C, Pike MC, Forman D, Fogelman K \& Wadsworth ME. Apparent doubling of frequency of undescended testis in England and Wales in 1962-1981. Lancet 19842 330-332.

60 Campbell DM, Webb JA \& Hargreave TB. Cryptorchidism in Scotland. British Medical Journal 1987295 1235-1236.

61 Thorup J \& Cortes D. The incidence of maldescended testes in Denmark. Pediatric Surgery International 19905 2-5.

62 Boisen KA, Kaleva M, Main KM, Virtanen HE, Haavisto A-M, Schmidt IM, Chellakooty M, Damgaard IN, Mau C, Reunanen M, Skakkebæk NE \& Toppari J. Difference in prevalence of congenital cryptorchidism in infants between two Nordic countries. Lancet $20043631264-1269$.

63 Ansell PE, Bennett V, Bull D, Jackson MB, Pike LA, Pike MC, Chilvers CED, Dudley NE, Gough MH, Griffiths DM, Redman C, Wilkinson AR, MacFarlane A \& Coupland CAC. Cryptorchidism: a prospective study of 7500 consecutive male births, 19841988. Archives of Disease in Childhood 199267 892-899.

64 Pierik FH, Burdorf A, Deddens JA, Juttmann RE \& Weber RF. Maternal and paternal risk factors for cryptorchidism and hypospadias: a case-control study in newborn boys. Environmental Health Perspectives 2004112 1570-1576.

65 Buemann B, Henriksen H, Villumsen ÅL, Westh A \& ZachauChristiansen B. Incidence of undescended testis in the newborn. Acta Chirurgica Scandinavica $1961283289-293$.

66 Cryptorchidism: an apparent substantial increase since 1960. John Radcliffe Hospital Cryptorchidism Study Group. British Medical Journal 1986293 1401-1404.

67 Kallen B, Bertollini R, Castilla E, Czeizel A, Knudsen LB, Martinez-Frias ML, Mastroiacovo P \& Mutchinick O. A joint international study on the epidemiology of hypospadias. Acta Paediatrica Scandinavica 1986324 1-52.

68 Dolk H, Vrijheid M, Scott JE, Addor MC, Botting B, De Vigan C, De Walle H, Garne E, Loane M, Pierini A, Garcia-Minaur S, Physick N, Tenconi R, Wiesel A, Cazolari E \& Stone D. Toward the effective surveillance of hypospadias. Environmental Health Perspectives 2004112 398-402.

69 Pierik FH, Burdorf A, Nijman JM, de Muinck Keizer-Schrama SM, Juttmann RE \& Weber RF. A high hypospadias rate in The Netherlands. Human Reproduction 200217 1112-1115.

70 Paulozzi LJ, Erickson JD \& Jackson RJ. Hypospadias trends in two US surveillance systems. Pediatrics 1997100 831-834.

71 Dolk H. Rise in prevalence of hypospadias. Lancet 1998351770.

72 Porter MP, Faizan MK, Grady RW \& Mueller BA. Hypospadias in Washington State: meaternal risk factors and prevalence trends. Pediatrics 2005115 e495-e499.

73 Kallen B \& Winberg J. An epidemiological study of hypospadias in Sweden. Acta Paediatrica Scandinavica 1982293 1-21.

74 Virtanen HE, Kaleva M, Haavisto A-M, Schmidt IM, Chellakooty M, Main KM, Skakkebæk NE \& Toppari J. The birth rate of hypospadias in the Turku area in Finland. APMIS 2001109 96-100.

75 Boisen K, Chellakooty M, Schmidt I, Kai C, Damgaard I, Suomi AM, Toppari J, Skakkebæk NE \& Main KM. Hypospadias in a cohort of 1072 Danish newborn boys: prevalence and relationship to placental weight, anthropometrical measurements at birth, and reproductive hormone levels at 3 months of age. Journal of Clinical Endocrinology and Metabolism 200590 4041-4046.

76 Sørensen HR. Hypospadias. With special reference to etiology. Copenhagen: Munksgaard; Thesis 1953.

77 Weidner IS, Møller H, Jensen TK \& Skakkebæk NE. Risk factors for cryptorchidism and hypospadias. Journal of Urology 1999161 1606-1609.

78 Hussain N, Chaghtai A, Herndon CD, Herson VC, Rosenkrantz TS \& McKenna PH. Hypospadias and early gestation growth restriction in infants. Pediatrics 2002109 473-478. 
79 Fredell L, Kockum I, Hansson E, Holmner S, Lundquist L, Lackgren G, Pedersen J, Stenberg A, Westbacke G \& Nordenskjold A. Heredity of hypospadias and the significance of low birth weight. Journal of Urology 2002167 1423-1427.

80 Calzolari E, Contiero MR, Roncarati E, Mattiuz PL \& Volpato S. Aetiological factors in hypospadias. Journal of Medical Genetics 198623 333-337.

81 Akre O, Lipworth L, Cnattingius S, Sparén P \& Ekbom A. Risk factor patterns for cryptorchidism and hypospadias. Epidemiology $199910364-369$

82 Fredell L, Lichtenstein P, Pedersen NL \& Svensson J. Hypospadias is related to birth weight in discordant monozygotic twins. Journal of Urology 1998160 2197-2199.

83 De Zegher F, Francois I, Boehmer ALM, Saggese G, Müller J, Hjort O, Sultan C, Clayton P, Brauner R, Cacciari E, Ibanez L, Van Vliet G, Tiulpakov A, Saka N, Ritzen M \& Sippell WG. Androgens and fetal growth. Hormone Research 199850 243-244.

84 Francois I, Van Helvoirt M \& De Zegher F. Male pseudohermaphroditism related to complications at conception, in early pregnancy or in prenatal growth. Hormone Research 199951 91-95.

85 Chellakooty M, Schmidt IM, Haavisto A-M, Boisen KA, Damgaard IN, Mau C, Petersen JH, Juul A, Skakkebæk NE \& Main KM. Inhibin A, Inhibin B, follicle-stimulating hormone, luteinizing hormone, estradiol, and sex hormone-binding globulin levels in 473 healthy infant girls. Journal of Clinical Endocrinology and Metabolism 200388 3515-3520.

86 Hughes IA, Northstone K, Golding J \& ALSPAC study team. Reduced birth weight in boys with hypospadias: an index of androgen dysfunction? Archives of Disease in Childhood 200287 F150-F151.

87 Hutson JM, Baker M, Terada M, Zhou B \& Paxton G. Hormonal control of testicular descent and the cause of cryptorchidism. Reproduction, Fertility, and Development 19946 151-156.

88 Toppari J. Physiology and disorders of testicular descent. Endocrine Development 20035 104-109.

89 Ivell R \& Hartung S. The molecular basis of cryptorchidism. Molecular Human Reproduction 20039 175-181.

90 Cortes D, Thorup JM \& Visfeldt J. Cryptorchidism: aspects of fertility and neoplasms. A study including data of 1335 consecutive boys who underwent testicular biopsy simultaneously with surgery for cryptorchidism. Hormone Research $20015521-27$.

91 Giwercman A, Grindsted J, Hansen B, Jensen OM \& Skakkebæk NE. Testicular cancer risk in boys with maldescended testis: a cohort study. Journal of Urology 1987138 1214-1216.

92 Moller H, Cortes D, Engholm G \& Thorup J. Risk of testicular cancer with cryptorchidism and with testicular biopsy: cohort study. British Medical Journal 1998317729.

93 Lee PA, O'Leary LA, Songer NJ, Coughlin MT, Bellinger MF \& LaPorte RE. Paternity after bilateral cryptorchidism: a controlled study. Archives of Pediatrics and Adolescent Medicine $1997151260-263$.

94 Lee PA, Coughlin MT \& Bellinger MF. Paternity and hormone levels after unilateral cryptorchidism: association with pretreatment testicular location. Journal of Urology 2000 164 1697-1701.

95 Lee PA \& Coughlin MT. Leydig cell function after cryptorchidism: evidence of the beneficial result of early surgery. Journal of Urology $20021671824-1827$.
96 Cortes D, Thorup J \& Lindenberg S. Fertility potential after unilateral orchidopexy: an age independent risk of subsequent infertility when biopsies at surgery lack germ cells. Journal of Urology $1996156217-220$.

97 DeMuinck-Keizer SS, Hazebroek FW, Drop SL, Degenhart HJ, Molenaar JC \& Visser HKA. Hormonal evaluation of boys born with undescended testes during their first year of life. Journal of Clinical Endocrinology and Metabolism 1988 66 159-164.

98 Gendrel D, Job JC \& Roger M. Reduced post-natal rise of testosterone in plasma of cryptorchid infants. Acta Endocrinologica $1978 \mathbf{8 9} 372-378$.

99 Job JC, Toublanc JE, Chaussain JL, Gendrel D, Garnier P \& Roger M. Endocrine and immunological findings in cryptorchid infants. Hormone Research 198830 167-172.

100 Barthold JS, Manson J, Regan V, Si X, Hassink SG, Coughlin MT \& Lee PA. Reproductive hormone levels in infants with cryptorchidism during postnatal activation of the pituitary-testicular axis. Journal of Urology 2004172 1736-1741.

101 Suomi AM, Main KM, Kaleva M, Schmidt IM, Chellakooty M, Virtanen HE, Boisen KA, Damgaard IN, Kai CM, Skakkebæk NE \& Toppari J. Hormonal changes in 3-month-old cryptorchid boys. Journal of Clinical Endocrinology and Metabolism $2006 \mathbf{9 1}$ 953-958

102 Andersson A-M, Jørgensen N, Larsen LF, Rajpert-De Meyts E \& Skakkebæk NE. Impaired Leydig cell function in infertile men: a study of 357 idiopathic infertile men and 318 proven fertile controls. Journal of Clinical Endocrinology and Metabolism 200489 3161-3167.

103 Cortes D, Thorup J, Lindenberg S \& Visfeldt J. Infertility despite surgery for cryptorchidism in childhood can be classified by patients with normal or elevated follicle-stimulating hormone and identified at orchidopexy. British Journal of Urology International 200391 670-674.

104 Cendron M, Keating MA, Huff DS, Koop CE, Snyder HM \& Duckett JW. Cryptorchidism, orchiopexy and infertility: a critical long-term retrospective analysis. Journal of Urology 1989142 559-562.

105 Grasso M, Buonaguidi A, Lania C, Bergamaschi F, Castelli M \& Rigatti P. Postpubertal cryptorchidism: review and evaluation of the fertility. European Urology 199120 126-128.

106 Rusnack SL, Wu HY, Huff DS, Snyder HM III, Carr MC, Bellah RD, Zderic SA \& Canning DA. Testis histopathology in boys with cryptorchidism correlates with future fertility potential. Journal of Urology $2003169659-662$.

107 Mieusset R \& Soulie M. Hypospadias: psychosocial, sexual, and reproductive consequences in adult life. Journal of Andrology 200526 163-168.

108 Feyaerts A, Forest MG, Morel Y, Mure PY, Morel-Journel N, Mallet D, Nicolino M, Chatelain P, David M \& Mouriquand P. Endocrine screening in 32 consecutive patients with hypospadias. Journal of Urology $2002 \mathbf{1 6 8} 720-725$.

109 Gearhart JP, Donohoue PA, Brown TR, Walsh PC \& Berkovitz GD. Endocrine evaluation of adults with mild hypospadias. Journal of Urology $1990 \mathbf{1 4 4} 274-277$.

110 Jugenburg I \& Kipikasa A. Fertility in patients with hypospadias. Acta Chirurgiae Plasticae 198830 86-93.

111 Baskin LS. Hypospadias and urethral development. Journal of Urology $2000163951-956$.

Received 10 May 2006

Accepted 21 June 2006 